\title{
Visual Politics in American Dance Film: Representation and Disparity
}

Cara Hagan, Appalachian State University, Director and Curator for ADF's Movies by Movers

\begin{abstract}
This article explores stylistic and demographic commonalities in American dance film through the curatorial lens of American Dance Festival's Movies by Movers, an international dance film festival. While calling into question how the dance film community can be more aware of the culture created on screen by makers and presenters, I reveal instances of representational disparity found in American dance film while examining the relationship of dance film to ideologies perpetuated by mass media and the world of professional dance.
\end{abstract}

Keywords: race, gender, mass media, curating, American Dance Festival

As director of the internationally recognized American Dance Festival's Movies by Movers (founded in 2010 as Movies by Movers; hereafter referred to by its official name, ADF's Movies by Movers), I see hundreds of dance film projects every year through submissions, artist inquiry, social media, other dance film festivals, and my own searching through internet platforms. Like many dance film enthusiasts, makers, and curators, I am invested in the cultivation and promotion of dance film. To that end, I am interested not only in seeing what is being made for the sake of creating a program each year, but I am compelled to question what I see within the projects I view, to better understand the landscape and trajectory of this art form I serve.

In recent years, I've begun to notice the stylistic and demographic commonalities seen across dance films as possessing a particular kind of visual politics. While the term visual politics is not new, I propose to use the term to consider the vast collection of dance films received through the submission process to ADF's Movies by Movers and the resultant culture that reveals the values and ideals inherent in our art form and our community.1 In this writing my focus will be on American projects, as the largest number of submissions to ADF's Movies by Movers come from the United States, and the complexities of demographics (most specifically racial demographics) across the world beg more explanation than this short provocation can provide.

To further define the term in this context, I consider visual politics to refer to the people and situations we see on screen with respect to the culture created by dance 
film makers and presenters. It is a scene influenced by socio-cultural norms in the real world, and affected by the lens through which we view the arts and arts industries. For dance film that means that while we strive for our art form to be an experimental, open-source platform, the challenges to stylistic and demographic diversity found in mainstream media and professional dance are our own. This is not to say that dance film is not innovative or unique in comparison to professional dance and mainstream filmmaking, though I would argue that to truly challenge the status quo, the dance film community must begin to question those things that keep us bound to the whims and aesthetics of our forerunners.

In order to understand the visual politics of dance film, I started by looking at its stylistic repetitions. What kind of movement is being featured most often? What kinds of spaces and locations are people using in their films? What type of sound or music is being used most often? What do the stylistic representations found in dance film say about the ways we perform and perpetuate ideas of societal constructs like race and gender? And while some homogeny is necessary in any art form to separate one form from another and to create boundaries for definition, too much restraint on what might be included in the parameters of an art form is limiting. For example, most projects that I receive could be categorized as featuring modern or contemporary movement. This is no surprise, as many of those we consider pioneers in dance film practiced modern and contemporary aesthetics. Modern and contemporary dance is also the primary movement practice taught in the Western collegiate/university system and the primary aesthetic found at large dance festivals across the country, including the American Dance Festival. Because of this, we are often compelled to believe that this is the aesthetic for dance film. While modern and contemporary dance is experimental, includes a range of dynamic qualities, and allows the creativity of both the choreographer and the dancer to be accentuated, the overarching philosophies found in arts education today do not account for or recognize the same experimental spirit found in dance forms not privileged in the academy-hip hop, for example.2

Hip hop is historically an experimental art form in the sense that it developed as a fringe endeavor by teenagers in the streets of 1970s New York, and practitioners pride themselves on originality of movement and style as a primary tenet of the form. The hip hop we often see in mainstream media coming from Hollywood and television networks-ideological entities that largely influence our perception of the form-do not often reference this history of invention and largely leave out the aesthetics we might find in non-commercial spaces, like a hip hop battle. It is here, inside the cypher (battle circle), where dancers/choreographers face off to see who can be the most spontaneous and innovative. While over the past three seasons of curating ADF's Movies by Movers, I have seen a marginal rise in the number of submissions featuring hip hop, forms other than modern/contemporary still appear to be fighting for a place 
among the dance film constellation. At the same time, hip hop continues to find a place in mainstream media and more specifically in music videos-a genre of filmmaking that has become increasingly bound to digital platforms such as Tidal, Vevo, and iTunes as networks like MTV show less music in favor of reality TV.

Like dance film, music videos are meant to push the boundaries of kinetic and musical imagery. The music videos of this millennium look vastly different than those of the early days of music videos, boasting complex choreography, cutting edge editing effects, and innovative conceptual aesthetics. Rapper Missy Elliott has been consistently praised for cinematic inventiveness and choreography in her videos throughout her two-decade career in hip hop music. One of her most recent videos, Where They From (2015), directed by Dave Myers and choreographed by Nadine "HiHat" Ruffin, features all the tenets of what is generally agreed upon as a dance filmit's site specific, camera specific, and edit specific.s And while it has a commercial purpose, the video features several movement sections that speak to the experimental aims of dance film. The most experimental section of the piece appears near the end of the video. There is a series of cardboard boxes arranged in a grid on the floor. A group of dancers dressed in non-gender-conforming plastic outfits pop in and out of the boxes, jumping from one to another, creating different configurations of dancing groups. Sometimes only legs are visible coming out of the tops of the boxes, sometimes dancers are seen from the waist up, contorting their shoulders and arms into asymmetrical shapes. The camera sees the dancers from a frontal view, in closeup, and from above. It makes quick movements with the dancers as they pop and lock. The box scene is perhaps the most compelling part of the video and taken out of context, could stand alone as a non-commercial exploration of space and shape. Further, with an almost exclusively of-color cast, the video goes against demographic norms found in dance film which I discuss later. Similar examples can be made of world dance forms and "non-dance" movement practices so often left out of the conversation in Western arts training and performance, especially those which feature improvisation or individualistic expression (unlike ballet, for example, that asks practitioners to adhere to a codified set of standards of practice) as a main aesthetic of the form.

As I've sought to understand the visual politics of dance film, I've also delved into the demographics associated with the films received through the submission process. In terms of issues of gender, race, age, and ability, the dance film world boasts shining examples of why dance film has the potential to be such a transcendent platform for featuring bodies not considered suitable for the concert stage or a Hollywood movie. However, in considering the demographics found through observing the submission process to ADF's Movies by Movers, there are areas of disparity that demand examination. For the purposes of this provocation, I will focus on gender and race, while recognizing that age and ability are important pieces of the puzzle to 
understand the cultural landscape of dance film. The numbers presented below are estimates, as it is impossible for me to know how each performer, choreographer, and director tallied self-identifies. To ensure as much accuracy as possible, I have used artist social media profiles, websites, and additional video work to determine if my initial impression of a participant is correct. Trends have appeared over the past four seasons that are compelling and speak to the landscape and culture we (makers, curators, and educators) are actively building, which I hope to illuminate through my analysis.

In 2015, I explored what it means to be a feminist in the 21 st century and what it means to make feminist art in the context of dance film. In that research I stated:

For many women and feminist allies, dance film has created a space apart from mainstream media and the traditions of professional dance to practice principles of feminism, including rectifying the presentation of the female body, confronting issues of race, class, and cultural identity, while making room for the kind of creative, intentional activism that has continued to characterize third-wave feminism.4

I also expressed concern over the limited inclusion of men in dance film, bringing into question concepts of male oppression through societal conditioning and structural repression which silences men's voices in favor of a constructed masculine persona.5 We know that in American dance film, male bodies are seen less often than female bodies due to the persistent view of dance being an emasculating activity. 6 While we have seen some progress in male representation in dance through mass media, gender norms persist in non-dance-related media where men and women move in prescribed gendered vocabularies in dance-centric movies and shows like So You Think You Can Dance. In 2005 for example, the show harshly berated dancer Anthony Bryant for being "too feminine" in his dancing with a rhythmic gymnastics ribbon during his audition.7 Even after inviting Bryant back the following season to reconcile the incident, the show largely continues to present traditional gender norms through the choreography presented in the show. Other shows like Dancing with the Stars further perpetuate traditional gender norms and feature male dancers as providers of spectacle and little else.

In all 24 seasons of Dancing with the Stars, spanning from 2005 to 2017, there have been male athletes featured on the show. These male athletes are praised for their physicality, but are not generally encouraged to take up dancing as more than a hobby. While all of the men who have danced, or are dancing on the show are not athletes, most fit into the heteronormative view of masculinity and in some way help to perpetuate a hyper-masculine ideology through the ways they speak, and are spoken about on the show, and how the dance numbers are choreographed, costumed, and performed. Chaz Bono, a transgender activist, made his appearance on the 13th season (September-November 2011) of the Dancing with the Stars, and 
because of his non-gender-conforming identity and his less-than-athletic build, he was subject to ridicule from both the general public and the judges. Most notably, Judge Bruno Tonioli called Bono a "Penguin" and an "Ewok," when describing his body in movement.8 On the show, Bono said, "You know, I came on this show so I could show America a different kind of man. And I know that if there was somebody on TV like me when I was growing up, my whole life would have been different." 9 So while dance studios and collegiate dance programs may be experiencing slowly rising numbers of male dancers in their ranks due to the increased visibility of dance in mass media, young men continue to endure stigma and harassment in their pursuit of this art form. 10

In 2017, just 30 percent of the performers counted in American-based projects submitted to ADF's Movies by Movers were men, and that number was only slightly higher for the 2015 and 2016 seasons, at around 35\%. According to the 2016 USA census, women account for $51 \%$ of the population, and men account for $49 \%$ of the population. What would dance film look like if the numbers of men and women seen on screen across projects were more representative of the American population? Would we see more varied expressions of gender? Would we see greater diversity of dance styles represented in dance film? It is not only in front of the camera where we see a gender disparity in dance film, it exists behind the camera, too. White, female choreographers consistently account for over half of all choreographers represented in any given season of ADF's Movies by Movers submissions, while male choreographers have accounted for only about one quarter of all choreographers in the submission pools across the 2015, 2016, and 2017 seasons. The picture is similar for directors, with male directors representing on average, 35\% of all directors represented in the submission pools for the 2015, 2016, and 2017 seasons. In the mainstream world of filmmaking, women continue to fight for better representation both on screen, and off. As mentioned earlier, dance film is an answer to that desire for greater freedom of expression for women and an opportunity to take on leadership roles traditionally reserved for men. However, does dance film get to claim that it creates a platform for equality, if the representational tables are turned because of a societal stigma toward men in the arts?

With regard to race in dance film, bodies of color are seen far less often than white bodies, as the struggle to normalize bodies of color on stage and on screen in the mainstream is ongoing. It is widely reported that the structure and availability of arts education in the United States often leaves would-be artists of color behind.11 This is echoed in the projects that are submitted to ADF's Movies by Movers, with the majority of the makers having honed their skills in American institutions of higher education. In fact, $66 \%$ of all the performing bodies featured in American submissions to ADF's Movies by Movers for 2017 were white, and numbers were similar for the 2015 and 2016 seasons.12 Numbers of performers of color rose steadily in alignment with rising 
submission numbers overall between 2012-when the number of white performers versus performers of color was found to be above 80 percent-and 2014. While the increase in performers of color is encouraging, it still means that curatorial options featuring bodies of color continue to be more limited then selections featuring white bodies, and this impacts how many bodies of color actually make it to the screen each year to be seen by the public. Since numbers have plateaued since 2015, the number of bodies of color seen on screen in ADF's Movies by Movers remains around 35\%. This year, $18 \%$ of all the bodies featured in the American submissions to the 2017 festival were female bodies of color. More than twice that amount accounts for the numbers of white female bodies seen in 2017.13 Men of color represented 16\% in 2017, and that number was only $10 \%$ in 2016 . Men of color are consistently the least represented performers in projects submitted to ADF's Movies by Movers. If there is a spike in the numbers of men of color seen in the submission pool, it is almost always attributed to films that feature a large number of people of color that skew the data, and not an even distribution of people across projects.

In 2017, the UCLA Ralph J. Bunche Center for African American Studies published their annual report on the entertainment industry, Hollywood Diversity Report: Setting the Record Straight. In addition to noting that minorities seen on screen are consistently underrepresented and have been since the first report was published in 2014, the authors also pointed out discrepancies behind the camera.14 In 2015 (the year which the 2017 report examines), just $10 \%$ of Hollywood directors were people of color. From 2015 to 2017 directors of color made up 20\% of ADF's Movies by Movers films. While this may be high in comparison to the film industry, dance film seems a long way from having a directorial landscape representative of the growing minority in the United States.15 The same is true of choreographers, with only $25 \%$ of all choreographers tallied in 2017 being choreographers of color. Again, men of color are the least represented in this group. If dance film were to become more representative of our population in the United States, what would change about dance film? Could better racial representation in dance film help the arts community as a whole be more open to variations in the types of bodies that are considered pleasing or compelling to watch? How can dance film disrupt the notion that young, white, female bodies are the most desirable bodies in dance film? How can we set ourselves apart from the mainstream, not just in our conceptual explorations, but in who carries out these explorations? Anecdotally, it seems that more of the films received through the submission process between the 2015 and 2017 seasons especially, address issues of identity politics, social justice, cultural heritage, and ask what experimentation looks like across those contexts.

If we consider dance film to occupy the same space as mass media-a space which perpetuates ideology - these questions are in keeping with Stuart Hall's exploration of race in mass media: 
The media are not only a powerful source of ideas about race. They are also one place where ideas are articulated, transformed and elaborated.16

While dance film does not occupy the same space or enjoy the same amount of visibility of more mainstream offerings, the dance film community must admit that what is produced, screened, and viewed matters. We are part of a larger conversation and we have the power to sway opinions about the bodies in front of and behind the camera. We have the power to make commentary on aesthetics too. In our reluctance to confront the issues I've discussed head-on, I believe we are hampering ourselves from emerging fully into the ethos of the 21 st century, a century where art and mass media are more intertwined than ever before, the minority will soon become the majority in our citizenry, and women and men may be on the verge of gender equality. My hope is that by sharing the ongoing aesthetic and demographic research through the ADF's Movies by Movers, others might be inspired to become more active participants in creating a culture of art that speaks to our collective strengths and moves to creatively address our pitfalls.

\section{Biography}

Cara Hagan is an interdisciplinary artist whose practice is informed by movement, words, and digital space. A recipient of several grants and awards, most recently Cara received a 2014-2015 NCAC Choreographic Fellowship, a 2015 Sustainability in the Arts Grant, and a 2015-2016 University research Council Grant. Currently Cara is under contract to complete her first book, due out in 2018.

Email: hagangelbercm@appstate.edu

Website: http://www.carahagan.net

\section{Notes}

1 As stated in my definition of visual politics, the products we make, coupled with the presentation of those products is a culture unto itself. What we make, and how we present and talk about dance film speaks to the ideals we hold as a creative community.

2 Julie A. Kerr-Berry, "Dance Education," 50.

3 "WTF (Where They From)." 
${ }_{4}$ Cara Hagan, "The Feminist Body Reimagined," 49.

5 Idem, 63.

6 Maxine Leeds Craig discusses dance and contemporary popular culture, citing SYTYCD and Dancing with the Stars, noting that if men are expected to dance, they are expected to uphold ideals of masculinity. Sorry I Don't Dance, 15.

7 "Anthony Bryant."

${ }_{8}$ Aaron Parsley, "Chaz Bono," n.p.

9 lbid.

10 Both Leeds Craig and Douglas Reisner describe the societal stigma that follows boys and men who dance, both socially and professionally. It is most interesting to compare Leeds Craig's study of men and dance in the mainstream and Reisner's study of men in the realm of professional dance; the stigma begins in childhood and ultimately means less men make it to the professional level of dancing.

${ }_{11}$ Kerr-Berry, 48.

12 The numbers of white performers for the 2015 and 2016 seasons was $65 \%$ for both seasons.

${ }_{13} 46 \%$ of performers tallied for the 2017 season were white women.

14 Darnell Hunt, et al, 2017 Hollywood Diversity Report, 2-4.

15 According to the US Census, minorities make up nearly $40 \%$ of the population and are on track to become the majority by 2050 . Hunt, et al reference these numbers in the 2017 Hollywood Diversity Report.

16 Stuart Hall, "The Whites of Their Eyes," 82.

\section{References}

ADF's Movies by Movers. Curated by Cara Hagan. American Dance Festival, North Carolina. 2015-present.

"Anthony Bryant." So You Think You Can Dance. Season 1, 2005. YouTube https://www.youtube.com/watch?v=02ORL_kXaA8

Dancing With the Stars. ABC. 2009-2015. Television.

Hagan, Cara. "The Feminist Body Reimagined in Two Dimensions: An Exploration of the Intersections Between Dance Film and Contemporary Feminism." In Telory D.

Arendell and Ruth Barnes (Eds.) Dances Duet with the Camera: Motion Pictures. London: Palgrave Macmillan, 2016.49-65. https://doi.org/10.1057/978-1-137-59610-9_3 
Hall, Stuart. "The Whites of Their Eyes: Racist Ideologies and the Media." In Gail Dines and Jean M. Humez (Eds.) Gender, Race, and Class in Media: A Critical Reader. Thousand Oaks, CA: SAGE Publications, 2011.81-85.

Hunt, Darnell, Ana-Christina Ramon, and Michael Tran. 2017 Hollywood Diversity Report: Setting the Record Straight Rep. Vol 4. Ralph J Bunche Center for African American Studies, UCLA. http://www.bunchecenter.ucla.edu/index.php/2017/02/new-2017hollywood-diversity-report/

Kerr-Berry, Julie A. "Dance Education in an Era of Racial Backlash: Moving Forward as We Step Backwards." Journal of Dance Education 12.2 (2012): 48-53.

https://doi.org/10.1080/15290824.2011.653735

Leeds Craig, Maxine. Sorry I Don't Dance. New York: Oxford Press, 2014.

Parsley, Aaron. "Chaz Bono: Dancing Judges' Animal Comments are 'Disrespectful."' People. October 25, 2011. http://people.com/tv/dancing-with-the-stars-chaz-saysjudges-animal-comments-are-disrespectful/

Risner, Douglas. Stigma and Perseverance in the Lives of Boys Who Dance: An Empirical Study of Male Identities in Western Theatrical Dance Training. Lewiston, NY: Mellen, 2009.

So You Think You Can Dance. Fox. 2005-Present. Television.

"WTF (Where They From) Ft. Pharrell Williams." Dir. Dave Myers. Missy Elliott. 2015. YouTube. https://www.youtube.com/watch?v=KO_3Qgib6RQ 